\title{
ANALISIS PENGENDALIAN BAHAN BAKU JASA MAKLON DENGAN MENGGUNAKAN METODE EOQ (ECONOMIC ORDER QUALITY) BERBASIS BIG DATA LOGISTIK GUNA MEMINIMALISIR BIAYA PRODUKSI PADA PT BARATA INDONESIA (PERSERO)
}

\author{
Dina Eka Shofiana ${ }^{1}$, Dwi Novita Sari ${ }^{2)}$ \\ Fakultas Ilmu administrasi \\ Universitas Pesantren Tinggi Darul 'Ulum (Unipdu)Jombang \\ Email: dinaekashofiana@ fia.unipdu.ac.id
}

\begin{abstract}
ARTICLE INFO
ABSTRACT

Keywords:

This study aims to determine the control of raw materials by using EOQ (Economic

Quantity of Optimal Orders

Order Quality) method to minimize production costs in PT Barata Indonesia (Persero).

(EOQ),

This research uses Adeskriptif with qualitative approach.The results of this study

Total Inventory Cost, indicate that the control of raw materials using the EOQ (Economic Order Quallity) Security Supplies,

Reorder. method can minimize production costs in PT Barata Indonesia (Persero) as follows: Silica Sand raw material can minimize production cost of Rp 16,321,500. Fero Silicon minimize the production cost of Rp 7,520,550,000, the raw material of Fero Mangan Mc can minimize the cost of Rp 2,255,625,000, the raw material of Fero Mangan Hc can minimize the cost of Rp 1.098,600. the raw material of Scrap can minimize the cost of $R p 324,995,000$.
\end{abstract}

\section{PENDAHULUAN}

\subsection{Latar Belakang}

Suatu usaha yang dilakukan secara komersial selalu berorientasi untuk memperoleh manfaat atau keuntungan yang sebesar-besarnya. Adapun upaya ke arah tersebut hanya memungkinkan untuk diwujudkan dengan mengarahkan dan memanfaatkan segenap potensi atau sumber daya (resource) yang dimiliki untuk menciptakan dan menambah kegunaan (utility) suatu barang dan jasa. Untuk mengatur kegiatan tersebut, perlu dibuat keputusan-keputusan yang berhubungan dengan usaha-usaha untuk mencapai tujuan agar barang dan jasa yang dihasilkan sesuai dengan apa yang direncanakan. Untuk mencapai perencanaan tersebut maka diperlukan efesiensi di segala bidang. 
Salah satu cara untuk mewujudkannya dengan sistem perencanaan dan pengendalian persediaan. Masalah dari persediaan, yaitu terlalu banyaknya persediaan yang data persediaan tidak sama yang mengakibatkan perusahaan terancam kehilangan konsumen. Oleh sebab itu, diperlukan adanya perencanaan yang baik dari perusahaan yang saling berkompetisi dalam industri dan konsistensi dalam pengendalian aktivitas produksinya.

Hampir semua jenis perusahaan memiliki berbagai bentuk persediaan. Menurut Heizer,J.d (2015:553) persediaan adalah salah satu aset termahal dari perusahaan, mencerminkan sebanyak $50 \%$ dari total modal yang diinvestasikan. Suatu perusahaan menyimpan persediaan untuk berbagai alasan penting. Banyak perusahaan memandang persediaan untuk memenuhi permintaan pelanggan atas suatu produk. Sejumlah persediaan disimpan untuk mengantisipasi ketidakpastian permintaan musiman atau siklus. Perusahaan seringkali memiliki persediaan dalam jumlah besar untuk mendapatkan diskon harga dan menghindari terhadap kenaikan harga dimasa depan atau untuk memperoleh harga yang lebih rendah karena membeli dalam volume yang lebih besar. Banyak perusahaan yang memandang perlu untuk memiliki persediaan dalam proses produksi untuk menghindari penghentian atau penundaan dalam proses produksi, misalnya: pemogokan, kerusakan mesin, cuaca buruk, ketergantungan bahan impor yang memerlukan jangka waktu pengiriman cukup lama ataupun terlambatnya bahan pengiriman baku ke lokasi produksi.

Salah satu metode yang cukup efisien dalam mengelola pengendalian bahan baku adalah metode EOQ (Economic Order Quality). EOQ (Economic Order Quality) adalah teknik pengendalian persediaan yang meminimalkan total biaya pemesanan dan penyimpanan. (Heizer,J.d 2015:561). Metode EOQ (Economic Order Quality) berusaha mencapai tingkat persediaan yang seminimum mungkin, biaya rendah dan mutu yang lebih baik. Perencanaan metode EOQ (Economic Order Quality) dalam suatu perusahaan akan mampu meminimalisasi terjadinya kekurangan stok (out of stock)sehingga tidak mengganggu proses produksi dalam perusahaan karena ada efesiensi persediaan bahan baku di dalam perusahaan yang bersangkutan. Selain itu dengan adanya penerapan metode EOQ (Economic Order Quality) perusahaan akan mampu mengurangi biaya penyimpanan, penghematan ruang, baik untuk ruangan gudang dan ruangan kerja, menyelesaikan masalah-masalah yang timbul dari banyaknya persediaan yang menumpuk sehingga mengurangi risiko yang dapat timbul.

Perusahaan memerlukan suatu metode untuk mengendalikan persediaan bahan baku dan menetapkan tersedianya bahan baku dalam kuantitas dan waktu yang tepat. Untuk itu penulis tertarik mengangkat metode Economic Order Quantity (EOQ), dimana metode ini dapat meminimalisasi kesalahan dalam data persediaan, dan bafer stock yang ada dan pengendalian biaya . Metode ini dapat menjawab mengenai kondisi yang sering terjadi di perusahaan, yakni menentukan besar persediaan yang sesuai dengan kebutuhan perusahaan yakni tidak terlalu tinggi juga tidak terlalu rendah sehingga dapat menekan kerugian yang terjadi di perusahaan akibat kurang tepatnya perusahaan mengolah persediaan di perusahaan mereka, yang akan mengalami keterlambatan dalam operasional Produksi. 
Berdasarkan latar belakang diatas, penulis tertarik untuk melakukan penelitian dengan judul "Analisis Pengendalian Bahan Baku dengan Menggunakan Metode EOQ (Economic Order Quality) Guna Meminimalisir Biaya Produksi pada PT Barata Indonesia (Persero)".

\subsection{Rumusan Masalah}

Berdasarkan latar belakang diatas maka rumusan masalah pada penelitian ini adalah:

Apakah pengendalian bahan baku dengan menggunakan metode EOQ (Economic Order Quality) dapat meminimalisir biaya produksi pada PT Barata Indonesia (Persero)?

\subsection{Tujuan Penelitian.}

Untuk menganalisis dan mengetahui pengendalian bahan baku dengan menggunakan metode EOQ (Economic Order Quality) dapat meminimalisir biaya produksi pada PT Barata Indonesia (Persero).

\section{KERANGKA TEORITIS}

\subsection{MANAJEMEN PRODUKSI}

Produksi dalam suatu perusahaan merupakan suatu kegiatan yang cukup penting bahkan didalam berbagai pembicaraan. Dapat dikatakan bahwa produksi adalah dapurnya perusahaan tersebut. Apabila kegiatan produksi dalam suatu perusahaan tersebut akan ikut terhenti maka kegiatan dalam perusahaan tersebut akan ikut terhenti pula. Karena demikian pula seandainya terdapat berbagai macam hambatan yang mengakibatkan tersendatnya kegiatan produksi dalam suatu perusahaan tersebut. Maka kegiatan didalam perusahaan tersebut akan terganggu pula. Pengertian manajemen itu sendiri menurut Assauri (2004:12) kegiatan atau usaha yang dilakukan untuk mencapai tujuan dengan menggunakan atau mengkoordinasikan kegiatan-kegiatan orang lain. Sedangkan produksi menurut Assauri (2004:11) adalah kegiatan yang mentransformasikan masukan (input) menjadi hasil dari keluaran (output). Manajemen Produksi Menurut Assauri (2004:12) adalah kegiatan untuk mengatur dan mengkoordinasikan penggunaan sumber-sumber daya yang berupa Sumber Daya Manusia, Sumber Daya Alat dan Sumber Daya Dana serta bahan, secara efektif dan efisien untuk menciptakan dan menambah kegunaan (Utility)sesuatu barang dan jasa.

\subsection{PERSEDIAAN}

Menurut Handoko (2011:333) Persediaan (Inventory) adalah suatu istilah umum yang menunjukkan segala sesuatu atau sumber daya-sumber daya organisasi yang disimpan dalam antisipasinya terhadap pemenuhan permintaan. Sedangkan menurut Assauri (2016:225) persediaan atau inventory adalah suatu bagian yang penting dari bisnis perusahaan. Inventory ini tidak hanya penting untuk operasi produksi, tetapi juga berkontribusi untuk mencapai kepuasan pelanggan. Menurut Heizer,J.d (2015:553) persediaan adalah salah satu aset termahal dari perusahaan, mencerminkan sebanyak 50\% dari total modal yang diinvestasi.Menurut Handoko (2011:334) jenis persediaan ada beberapa macam, dimana setiap jenis 
mempunyai karakteristik khusus tersendiri dan cara pegelolaanya yang berbeda. Menurut jenisnya, persediaan dapat dibedakan atas:

1. Persediaan bahan baku (raw material), yaitu persdiaan baja, kayu, kain dan komponen lainnya yang digunakan dalam proses produksi. Bahan baku atau bahan mentah dapat diperoleh dalam proses produksi selanjutnya.

2. Persediaan komponen-komponen rakitan (purchased part/components), yaitu persediaan barang-barang yang terdiri dari komponen-komponen yang diperoleh dari perusahaan lain, dimana secara langsung dapat dirakit menjadi suatu produk.

3. Persediaan bahan pembantu atau penolong (suplies), yaitu persedian barang-barang yang diperlukan dalam proses produksi, tetapi tidak merupakan bagian atau komponen barang jadi.

4. Persediaan barang dalam proses (work in process), yaitu persediaan barang-barang yang merupakan keluaran dari tiap-tiap bagian dalam proses produksi atau yang telah diolah menjadi suatu bentuk, tetapi masih perlu diproses lebih lanjut menjadi barang jadi.

5. Persediaan barang jadi (finished goods), yaitu persediaan barang-barang yang telah sesuai diproses atau diolah dalam pabrik dan siap untuk dijual atau dikirim kepada langganan.

\section{Model-Model Persediaan.}

Menurut Heizer (2015:560) model-model persediaan dapat dikelompokkan menjadi dua model yaitu:

1. Model Independen terdapat tiga model persediaan independenden yaitu:

a. Model kuantitas pesanan ekonomi (EOQ), model ini adalah salah satu teknik pengendalian persediaan yang paling sering digunakan.

b. Model kuantitas pesanan produksi, model ini berguna saat persediaan menumpuk secara berkelanjutan selama waktu tertentu dan saat asumsi kuantitas pesanan berlaku. Model ini dapat digunakan dalam dua situasi yaitu: saat persediaan mengalir atau menumpuk secara berkelanjutan selama suatu waktu setelah pesanan ditempatkan, saat unit-unit dihasilkan dan dijual secara serempak.

c. Model diskon kuantitas, model ini penggunaan diskon kuantitas (quality discount) hanyalah pengurangan harga $(\mathrm{P})$ untuk sebuah barang jika dibeli dalam kuantitas besar.

d. Model Probabilistik, model-model persediaan digunakan ketika permintaan produk tidak diketahui, tetapi dapat ditentukan menggunakan distribusi probabilitas. Menurut Pardede (2007:468) model ini terdiri dari dua model yaitu:

a) Sistem Q (Q-system) atau sistem jumlah/pemesanan kembali.

b) Sistem $\mathrm{P}(P$-system $)$ atau sistem berkala. 


\subsection{PENGENDALIAN.}

\section{Pengertian Pengendalian.}

Menurut Baroto (2006:52) Pengendaliaan persediaan merupakan fungsi manajerial yang sangat penting. Bila persediaan dilebihkan, biaya penyimpanan dan modal yang diperlukan akan bertambah. Bila perusahaan menahan terlalu banyak modalnya dalam persediaan, menyebabkan biaya penyimpanan yang berlebihan. Kelebihan persediaan juga membuat modal menjadi macet, semestinya modal tersebut dapat diinvestasikan pada sektor lain yang lebih menguntungkan (opportunity cost). Sebalikanya bila persediaan dikurangi, suatu ketika bias mengalami stock out (kehabisan barang). Bila perusahaan tidak memiliki persediaan yang mencukupi, biaya pengadaan darurat akan lebih mahal. Dampak lain, mungkin kosongnya barang di pasaran dapat membuat konsumen kecewa dan lari ke merk lain.

Menurut Nurnajamuddin (2012:146), bahwa pengendalian persediaan (Inventory) merupakan pengumpulan atau penyimpanan komoditas yang akan digunakan untuk memenuhi permintaan dari waktu ke waktu.

Jadi pengendalian persediaan adalah suatu usaha yang dilakukan oleh perusahaan untuk menjaga kebutuhan bahan baku dalam proses produksi terhadap kelancaran proses produksi.

\section{Tujuan Pengendalian.}

Pengendalian persediaan yang dijalankan oleh perusahaan pasti mempunyai alasan-alasan tertentu. Menurut Pardede (2005:458) alasan-alasan utama untuk mengadakan sediaan adalah dalam kaitanya dengan hal-hal berikut:

1. Berjaga-jaga adalah sediaan yang diadakan dengan maksud untuk berjaga-jaga terhadap kemungkinan tidak tersediaanya atau tidak cukupnya bahan-bahan pada saat dibutuhkan. Pengadaan sedian dapat dipandang sebagai cara untuk berjaga-jaga terhadap kemungkinan tidak tersediaanya atau tidak cukupnya bahan-bahan pada saat dibutuhkan. Kemungkinan seperti itu terjadi apabila permintaan berubah-ubah atau tidak bisa dapat diramalkan. Penyebab lainnya adalah masa tunggu (lead time) yang berubah-ubah dan sering tidak dapat diperkirakan. Penyebab itu dapat juga kedua-duanya terjadi sekaligus, yaitu permintaan tidak pasti. Sediaan yang diadakan dengan maksud untuk berjaga-jaga terhadap kemugkinan seperti itu disebut sediaan berjaga-jaga (buffer stock).

2. Pemisahaan kegiatan adalah pengurangan ketergantungan antara pusat-pusat kerja. Pada suatu rangkaian kegiatan pengolahan, setiap kegiatan sangat bergantung kepada, atau dipengaruhi oleh kegiatan-kegiatan lainnya. Pada kegiatan yang berurutan, apabila satu kegiatan yang terhenti, maka kegiatan berikutnya akan terganggu. Untuk mengatasi hal ini maka dua kegiatan yang berurutan dapat dipisahkan dari segi sediaan. Dengan cara ini, suatu kegiatan yang mengikuti, atau yang merupakan lanjutan dari kegiatan lain dengan sediaan bahan dalam pengerjakan sehingga ketergantungannya terhadap kegiatan pendahuluannya dapat diperkecil.

Disamping itu pemisahan dari kegiatan dari sediaan juga dilakukan agar untuk setiap kegiatan dapat direncanakan jadwal secara bebas tanpa harus menyesuaikannya dengan jadwal- 
jadwal lain. Dengan demikian sediaan disini berperan sebagai alat memungkinkan pemisahan kegiatan (operations decoupling).

3. Pemulusan kegiatan pengolahan (smoothing production) adalah pengurangan tingkat perubahan jumlah barang yang dibuat. Apabila jumlah barang yang diminta berubah-ubah secara tidak teratur, perusahaan tidak harus menaik turunkan tingkat pengolahan untuk memenuhinya. Pengolahan dapat diusahakan agar selalu berada pada tingkat yang tetap dengan bantuan sediaan. Pada saat jumlah barang yang dibuat lebih besar dari jumlah yang minta maka sediaan akan menumpuk. Sediaan ini nantinya akan digunakan untuk menutupi kekurangan pada saat jumlah yang dibuat lebih rendah dari jumlah yang diminta.

4. Penghematan biaya penanganan sediaan. Pada suatu rangkaian kegiatan pengolahan, bahan-bahan mengalir mulai dari kegiatan tahap awal hingga kegiatan tahap akhir. Pergerakan bahan-bahan ini tenru akan saja membutuhkan biaya terutama pada kegiatan pengolahan yang terputus-putus (intermittent production process). Biaya ini, yang disebut biaya penanganan sediaan (material handling cost), dapat dihemat dengan caea mengadakan atau menempatkan sediaan di antara dua kegiatan yang berurutan.

5. Penghematan biaya pengadaan bahan (material procurement cost) akan dapat dihemat dengan jumlah (quality discont) yang ditawarkan oleh perusahaan pemasok. Potongan jumlah diperoleh apabila pembelian dilakukan dalam jumlah besar, dan pembelian dalam jumlah besar akan dimungkinkan dengan pengadaan persediaan.

Meskipun persediaan akan memberikan banyak manfaat bagi perusahaan, namun perusahaaan tetap hati-hati dalam menentukan kebijakan persediaan. Persediaan membutuhkan biaya investasi dan dalam hal ini menjadi tugas bagi manajemen untuk menentukan investasi yang optimal dalam persediaan. Masalah persediaan merupakan masalah pembelanjaan aktif, di mana perusahaan menemukan dana yang dimiliki dalam persediaaan dengan cara yang seefektif mungkin. Untuk melangsungkan usahanya dengan lancar maka kebanyakan perusahaan merasakan perlunya persediaan.

\subsection{EOQ (Economic Order Quality).}

\section{Pengertian EOQ (Economic Order Quality).}

Menurut Heizer,J.d (2015:561) EOQ (Economic Order Quality) adalah teknik pengendalian persediaan yang meminimalkan total biaya pemesanan dan penyimpanan.

Sedangkan menurut Mannulang (2005:70) EOQ (Economic Order Quality) adalah suatu cara untuk memperoleh cara untuk memperoleh sejumlah barang dengan biaya minimum dan adanya pengawasan terhadap biaya pemesanan (Ordering cost) dan biaya penyimpanan atau (Carrying cost).

Kemudian menurut Pardede (2005:422) menyatakan bahwa EOQ (Economic Order Quality) menunjukkan sejumlah barang yang harus dipesan untuk tiap kali pemesanan agar biaya sediaan keseluruhan menjadi sekecil mungkin. 


\section{Asumsi EOQ (Economic Order Quality)}

Asumsi EOQ (Economic Order Quality) menurut Heizer,J.d (2015:561) adalah sebagai berikut:

1. Jumlah permintaan diketahui, cukup konstan, dan independen.

2. Waktu tunggu yakni, waktu antara pemesanan dan penerimaan pesanan telah diketahui dan bersifat konstan.

3. Persediaan segera diterima dan selesai seluruhnya. Dengan kata lain, persediaan yang dipesan tiba dalam satu kelompok pada suatu waktu.

4. Tidak tersedia diskon kuantitas.

5. Biaya variabel hanya biaya untuk memasang atau memesan (biaya pemasangan atau pemesanan) dan biaya untuk menyimpan persediaan dalam waktu tertentu (biaya penyimpanan atau biaya untuk membawa persediaan).

6. Kehabisan (kekurangan) persediaan dapat sepenuhnya dihindari jika pemesanan dilakukan pada waktu yang tepat.

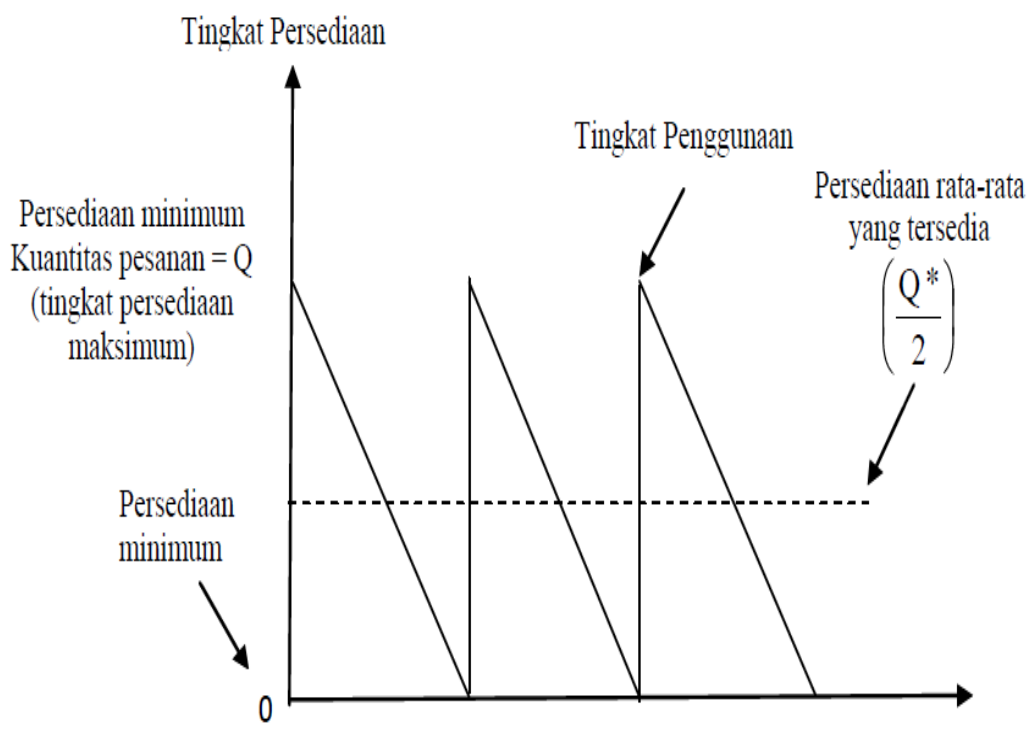

Gambar 2.1 Penggunaan Persediaan dalam Waktu Tertentu Sumber : Heizer,J.d (2015:561).

\section{Menentukan EOQ (Economic Order Quality)}

Menentukan pesanan persediaan ialah dengan menentukan berapa banyak jumlah persediaan yang dibutuhkan perusahaan dalam menjalankan kegiatannya. Untuk itu diperlukan metode EOQ (Economic Order Quantity) agar dapat menentukan kuantitas persediaan yang ekonomis.

Perhitungan EOQ menurut Heizer,J.d(2015:563) yaitu:

$\mathrm{EOQ}=\sqrt{\frac{2 D S}{H}}$

Keterangan:

EOQ = Jumlah optimum unit per pesanan 
$\mathrm{S}=$ Biaya pesanan untuk setiap pesanan

D $\quad=$ Permintaan tahunan dalam unit

$\mathrm{H} \quad$ = Biaya penyimpanan per unit per tahun

Selain rumus EOQ (Economic Order Quality), terdapat beberapa rumus untuk mendukung perhitungan biaya persediaan, antara lain:

1. Persediaan rata-rata tersedia $=\frac{Q^{*}}{2}$

2. Persediaan pesanan yang diperkirakan $=\mathrm{D}$

$$
\mathrm{Q}^{*}
$$

3. Biaya pemesanan tahunan $=\mathrm{D} \cdot \mathrm{S}$

$$
\mathrm{Q}^{*}
$$

4. Biaya penyimpanan tahunan $=\frac{Q^{*} \cdot H}{2}$

5. Total harga per unit $=$ Harga per unit $\times$ Biaya pesanan

6. Total biaya tahunan $=$ Biaya pemasangan $($ pesanan $)+$ Biaya penyimpanan .

\section{Persediaan Pengamanan (Safety Stock).}

Menurut Rangkuti (2007:10) persediaan pengaman (Safety stock) adalah persediaan tambahan yang diadakan untuk melindungi atau menjaga kemungkinan terjadinya kekurangan bahan (Stock out).

Rumus Persediaan Pengamanan (Safety Stock):

$$
\mathrm{Ss}=\mathrm{Z} \times \mathrm{S}
$$

$$
\text { Keterangan: }
$$

Ss = Safety stock atau persediaan pengaman

$\mathrm{Z}=$ Factor yang merupakan jumlah deviasi kepercayaan terhadap pelayanan atau safety factor yang besarnya ditentukan oleh tingkat service level

$\mathrm{S}=$ Standar deviasi permintaan selama tenggang waktu pemesanan atau standar deviation of demand over the lead time.

Untuk mencari standar deviasi rumusnya adalah sebagai berikut:

$\mathrm{S}=\sqrt{\frac{\sum X \cdot x^{2}}{N}}$

\section{Keterangan :}

$\mathrm{S}=$ Standar devisiasi.

$\mathrm{x}=$ Pemakaian bahan baku sesungguhnya.

$\dot{x} \quad=$ Pemakaian bahan baku rata-rata.

$\mathrm{N}=$ Jumlah data. 


\section{Pemesanan Kembali (Reorder Point)}

Menurut Heizer,J.d (2015:567) Pemesanan kembali (Reorder Point) adalah tingkat persediaan (titik) dimana untuk mengisiulang persediaan barang. Sedangkan menurut Assauri (2016:232) asumsi dari Pemesanan kembali (Reorder Point) yaitu:

1. Bahwa suatu perusahaan akan menempatkan suatu pesanan, bila tingkat persediaan (inventory)-nya untuk item tertentu telah mencapai nol.

2. Perusahaan akan menerima item yang dipesannya adalah seketika itu juga atau segera.

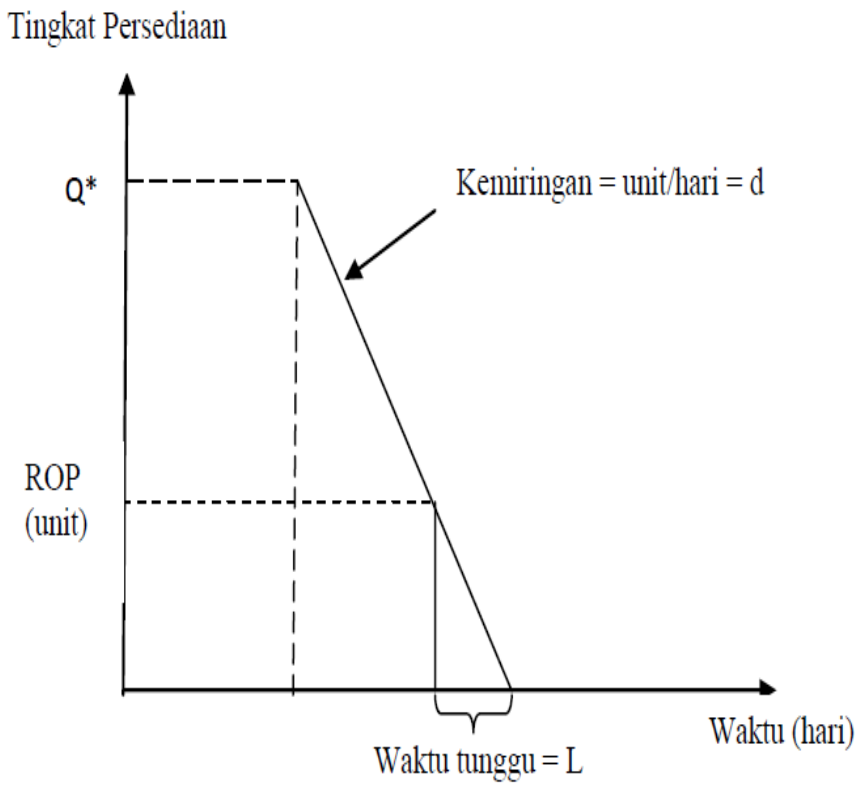

Gambar 2.2 Titik Pemesanan Ulang (ROP)

Sumber: Heizer,J.d (2015:568)

Keterangan: Q* adalah kuantitas pesanan optimum dan waktu tunggu mempresentasikan waktu antara penempatan pesanan dan penerimaan pesanan.

Rumus untuk menentukan pemesanan kembali (reorder point):

$$
\mathrm{ROP}=(\mathrm{d} \times \mathrm{L})+\mathrm{SS}
$$

Keterangan : $\mathrm{d}=$ Permintaan per hari

$\mathrm{L}=$ Waktu tunggu pesanan baru dalam hari

Persamaan ROP ini berasumsi bahwa permintaan selama waktu tunggu dan waktu tunggu itu sendiri adalah konstan. Permintaan per hari (d) dihitung dengan membagi permintaan tahunan (D) dengan jumlah hari kerja dalam setahun:

Permintaan per hari $(\mathrm{D})=$ D

Jumlah hari kerja dalam satu tahun. 


\section{METODE PENELITIAN}

\subsection{Desain Penelitian}

Menurut Sugiyono (2015:307) metode kualitatif adalah metode penelitian yang berlandaskan pada filsafat positivisme/enterpretif, digunakan untuk meneliti pada kondisi obyek yang alamiah, (sebagai lawannya adalah eksperimen) dimana peneliti adalah sebagai instrumen kunci, teknik pengumpulan data dilakukan secara trianggulasi (gabungan), analisis data bersifat induktif/kualitatif, dan hasil penelitian kualitatif lebih menekankan makna dari pada generalisasi.

\subsection{Lokasi Penelitian}

Lokasi penelitian adalah tempat dimana penulis melakukan kegiatan penilitian untuk memperoleh data-data yang diperlukan guna menjawab permasalahan yang telah ditetapkan. Adapun lokasi penelitian yang dilakukan penulis sesuai dengan judul yang diteliti adalah mengenai analisis pengendalian bahan baku dengan menggunakan metode EOQ (Economic Order Quality) guna meminimalisir biaya produksi pada PT Barata Indonesia (Persero) yang berada di Jln. Veteran No. 241 Gresik 61123. Sedangkan penelitian ini berlangsung bulan Desember 2017 sampai januari 2017.

\subsection{Subyek Penelitian}

Penelitian ini terfokus untuk menganalisis dan mengetahui pengendalian bahan baku dengan menggunakan metode EOQ (Economic Order Quality) pada PT Barata Indonesia (Persero) pada tahun 2017. Penelitian ini meliputi penentuan EOQ (Economic Order Quality), total biaya persediaan, biaya pengamanan (Safety Stock), pembelian kembali (Reorder Point). Dalam penelitian ini penulis fokus pada kegiatan produksi yang continue (tetap)yaitu faundry (besi dan baja cor) yang berada di workshop 1 yaitu produksi Bogie 9-C dikarenakan produksi tersebut merupakan kontrak terlama yang diterima oleh PT Barata Indonesia dan laba terbesar yang diterima oleh perusahaan. Untuk bahan baku peneliti mengambil bahan baku Pasir Silika, Pasir Fero Mangan HC, Fero Mangan LC dan Scraf karena bahan baku tersebut merupakan bahan bahan baku utama yang sering digunakan dan sering dibeli untuk produksi bogie.

\subsection{Teknik Pengumpulan Data}

Pengumpulan data dapat dilakukan dalam berbagai setting, berbagai sumber, dan berbagai cara. Bila dilihat dari setting-nya, data dapat dikumpulkan dari setting alamiah (natural setting). Bila dilihat dari sumber datanya, maka pengumpulan data dapat menggunakan sumber primer dan sumber sekunder.sumber primer adalah sumber data yang langsung memberikan data kepada pengumpul data dan sumber data sekunder merupakan sumber yang tidak langsung memberikan data kepada pengumpul data, misalnya lewat orang lain atau dokumen. Bermacam-macam teknik pengumpulan data ditunjukkan pada gambar 3.1 berikut. Berdasarkan gambar tersebut terlihat bahwa secara umum 
terdapat empat macam teknik pengumpulan data, yaitu observasi, wawancara, dan gabungan/trianggulasi.

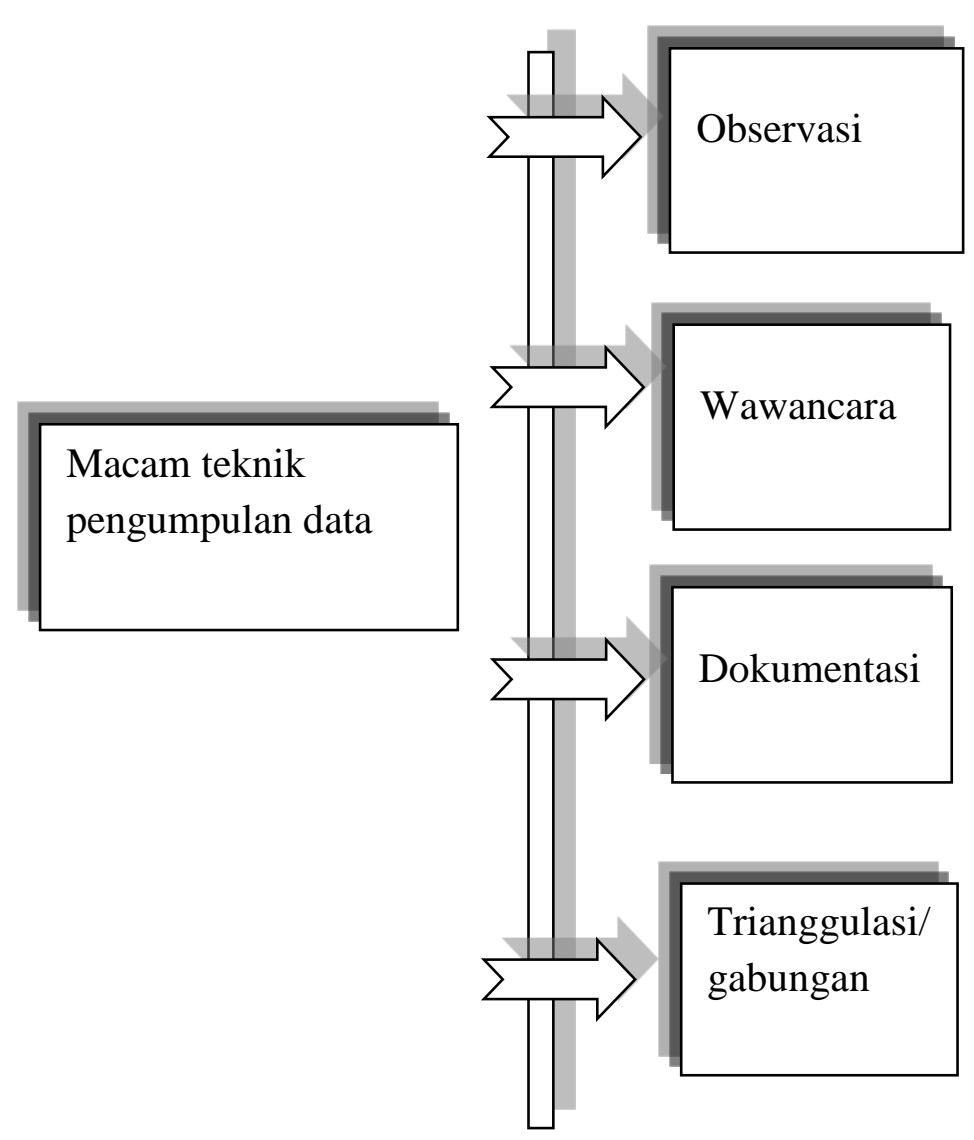

Gambar 3.1 Macam-macam Teknik Pengumpulan Data.

Sumber: Sugiyono (2016:357).

Dalam penelitian ini teknik pengumpulan data yang digunakan peneliti adalah sebagai berikut:

a. Observasi

Dengan mengamati secara langsung peneliti dapat mengetahui pengendalian bahan baku yang diterapkan pada PT Barata Indonesia (Persero). Observasi yang dilakukan peneliti adalah untuk memperoleh data yang diperlukan guna mengetahui pengendalian bahan baku dengan menggunakan metode EOQ (Economic Order Quality) pada PT Barata Indonesia (Persero).

b. Wawancara.

Dalam penelitian jenis wawancara yang digunakan peneliti adalaha wawancara semiterstruktur yaitu untuk menemukan permasalahan secara lebih terbuka, dimana fihak yang diajak wawancara diminta pendapat, dan ide-idenya. Dalam melakukan wawancara, peneliti perlu mendengarkan secara teliti dan mencatata apa yang dikemukakan oleh informan. (Sugioyono, 2015:387)

Dalam penelitian ini wawancara dilakukan dengan semua karyawan PT Barata Indonesia (Persero) yang berhubungan dengan tema peneliti khususnya pada divisi pengadaan, divisi pengendalian, perencaan dan control pada PT Barata Indonesia (Persero). 
c. Dokumentasi.

Dokumentasi merupakan catatan peristiwa yang sudah berlalu. Dokumentasi bisa berbentuk tulisan, gambar, atau karya-karya monumental dari seseorang (Sugiyono:2016:240).

Dalam penelitian ini dokumentasi mengumpulkan data-data dari pembelian bahan baku, penggunaan bahan baku, biaya pemesanan bahan baku dan biaya penympanan bahan baku. Serta mendokumentasikan bahan baku sesuai trase kode.

d. Trianggulasi

Triangulasi merupakan teknik pengumpulan data yang bersifat menggabungkan dari berbagai teknik pengumpulan data dan sumber data yang telah ada. (Sugiyono, 2016:241).

\subsection{Teknik Analisis data}

Analisis data dalam penelitian ini adalah analisis deskriptif dengan pendekatan kualitatif. Menurut Miles and Hubermen dalam Sugiyono (2016:246), mengemukakan bahwa aktifitas dalam analisis data kualitatif dilakukan secara terus-menerus sampai tuntas, sehingga datanya sudah jenuh. Aktivitas dalam analisis data, yaitu data reduction, data display, dan conclusion drawing/verification. Langkah-langkah analisis ditunjukkan pada gambar berikut:

Periode Pengumpulan

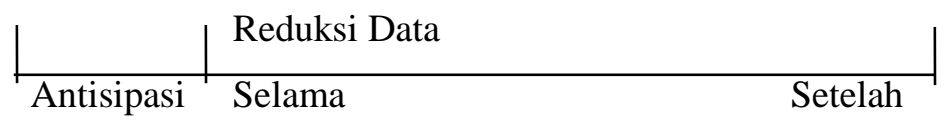

\begin{tabular}{|l|} 
Display data \\
\hline Selama
\end{tabular}

\begin{tabular}{|ll|} 
Kesimpulan/verifikasi & \\
\hline Selama & Setelah
\end{tabular}

Gambar 3.2 Komponen dalam analisis data (flow model).

Sumber: Sugiyono (2016:246).

Berdasarkan gambar tersebut terlihat bahwa:

1. Pengumpulan Data.

Data yang dikumpulan berupa kedatangan bahan baku, laporan penggunaan bahan baku, dan hasil finish good 
Setelah pengumpulan data, peneliti melakukan antisipasi sebelum reduksi data dilakukan. Setelah melakukan antisipasi, kemudian peneliti melakukan reduksi data. Reduksi data dengan memilih halhal pokok atau memfokuskan pada al-hal penting yag sesuai dengan kebutuhan penelitian.

3. Data Display (Penyajian Data).

Setelah data direduksi, maka langkah selanjutnya adalah menyajikan data. Data yang tersaji merupakan hasil dari perhitungan dari metode EOQ (Economic Order Quality) yang telah dihitung sesuai big data dengan menggunakan rumus kemudian data disajikan dalam bentuk tabel.

4. Conclusion Drawing/Verification (Penarikan Kesimpulan).

Penarikan kesimpulan dilakukan setelah dilakukan analisis perbandingan antara hasil pengendalian bahan baku yang dilakukan perusahan dengan pengendalian bahan baku dengan menggunakan metode EOQ (Economic Order Quality) .

\section{bagan Alir penelitian}
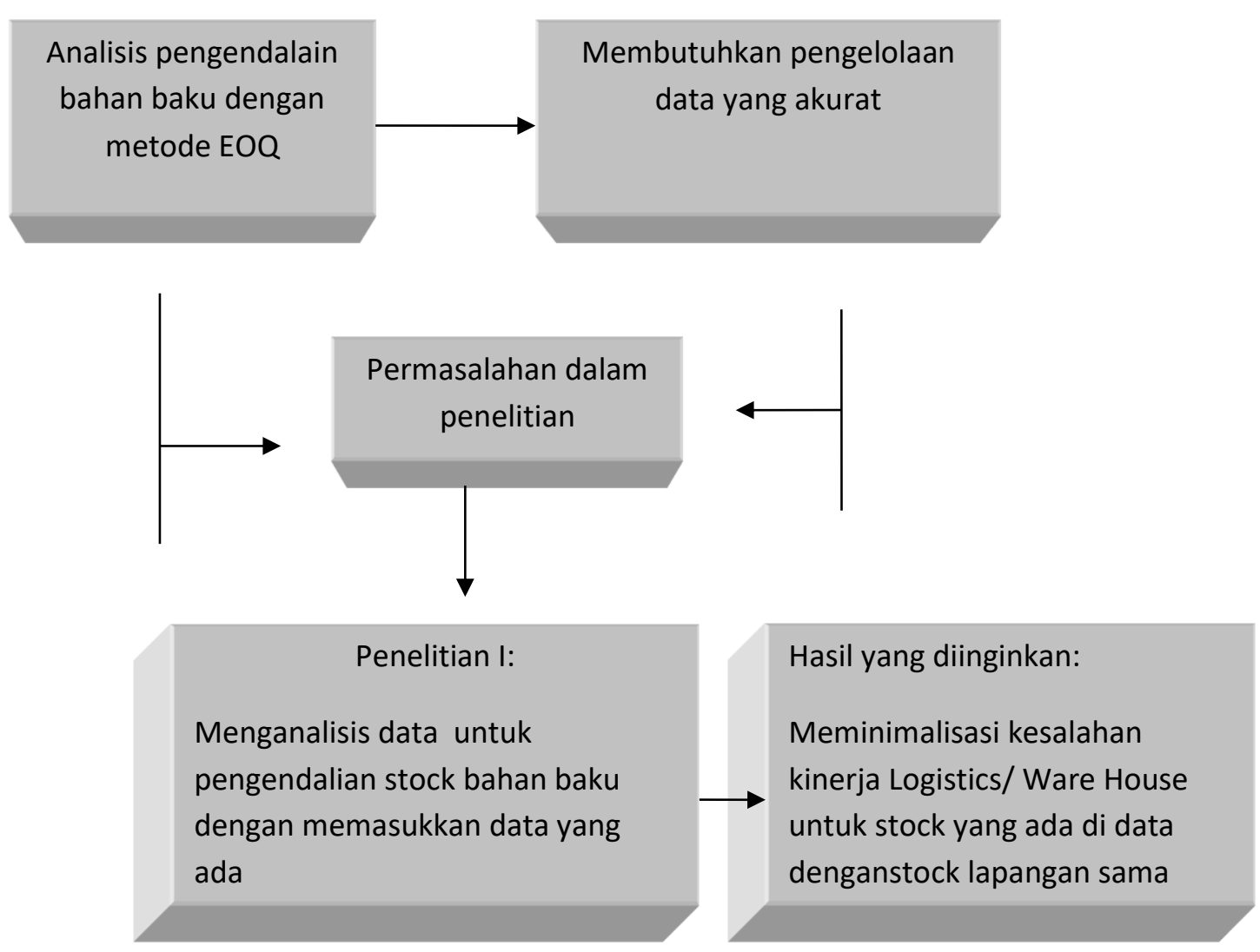

\section{HASIL PENELITIAN}

\subsection{Sistem Penanganan Bahan Baku di PT Barata Indonesia (Persero).}

\subsubsection{Permintaan pembelian dan pemesanan bahan baku di PT Barata Indonesia (Persero).}

Dalam hal ini transaksi pembelian bahan baku pada PT Barata Indonesia (Persero) diawali dari adanya pengajuan MRL (Material Requisition List) dari Divisi PPC (Perencanaan dan 
Pengendalian Control) kemudian bagian pengadaan membuat penawaran ke suplier setelah harga telah disepakati maka dibuatkan surat perjanjian, dalam surat perjanjian ada 2 yaitu SKBDN (Surat Kredit Berdokumen Dalam Negri) dan SPP (Surat Pesanan Pembelian) setelah surat itu diterbitkan maka proses pembelian dilakukan kepada suplier.

\subsubsection{Penggunaan Bahan Baku.}

Penggunaan bahan baku pada PT Barata Indonesia (Persero) disesuaikan dengan rencana produksi. Rencana tersebut yang didasarkan atas permintaan dari konsumen yang selanjutnya akan dikonfirmasikan ke bagian produksi. Berdasarkan ramalan produksi tersebut akan dapat diketahui bahan baku yang telah terpakai.

Penggunaan bahan baku dalam pelaksanan produksi terkadang tidak sama dengan perencanaan kebutuhan bahan baku, ini dikarenakan adanya hal-hal yang luput dari pengamatan yang telah dilakukan sebelumnya misalnya kerusakan mesin yang tidak dapat diduga sebelumnya atau karena produk yang cacat maka bahan baku yang digunakan akan semakin meningkat..

Dalam penelitian ini peneliti menggunakan produksi Bogie 9-C dengan bahan baku Pasir Silika, Fero Silikon, Fero Mangan Mc, Fero Mangan Hc, dan Scrap. Dari tabel 4.5 dapat dilihat bahwa penggunaan bahan baku selama tahun 2017 produksi Bogie 9-C yang digunakan bervariasi. Penggunaan terbesar pada bulan Desember yaitu 2000 ton untuk bahan baku Pasir Silika, 460 ton untuk Fero Silikon, 350 ton untuk Fero Mangan Mc, 230 ton untuk Fero Mangan Hc, 10000 ton untuk Scrap.

\subsubsection{Pembelian Bahan Baku.}

PT Barata Indonesia (Persero) melakukan pembelian bahan baku untuk memenuhi proses produksi. Untuk pembelian bahan baku Pasir Silika, Fero Silikon, Fero Mangan Mc, Fero Mangan Hc, dan Scraf bervariasi setiap waktunya.

Pembelian terbesar terjadi pada bulan Desember untuk bahan baku Pasir Silika sebanyak 2000 ton, untuk bahan baku Fero Silikon pada bulan Agustus sebanyak 1100 ton, untuk bahan baku Fero Mangan Mc pada bulan Desember sebanyak 500 ton, untuk bahan baku Fero Mangan Hc pada bulan Desember sebanyak 220 ton, dan untuk bahan baku Scrap pada bulan Desember sebanyak 20000 ton.

Berdasarkan wawancara dengan bagian pengadaan dan MRL (Material Requestion List) Tahun 2017 waktu tunggu pengiriman bahan baku Pasir Silika, Fero Mangan Mc, Fero Mangan Hc dan Scrap dilakukan secara bertahap yaitu selama 3 hari.

\subsubsection{Analisis Pengendalian Persediaan Bahan Baku Sebelum Menggunakan Metode EOQ (Economic Order Quality).}

PT Barata Indonesia (Persero) melakukan proses produksi secara terus menerus, perusahaan ini merupakan perusahaan Job Orderyaitu perusahaan melakukan proses produksi setelah ada kontrak pekerjaan. Dalam menentukan kebutuhan bahan baku perusahaan berpedoman pada 
pengalaman sebelumnya dan disesuaikan dengan rencana produksi serta untuk pengendalian bahan baku perusahaan terkadang menggunakan LIFO (Last in Firsh Out) dan FIFO (Firsh in Firsh Out). Perusahaan menentukan jumlah persediaan akhir dan keadaan bahan baku di gudang setiap hari. Pencatatan terhadap semua barang yang masuk atau keluar dari gudang juga dilakukan setiap hari. Walaupun demikian untuk perekapan yang dilakukan perusahaan masih bersifat manual.

Data pemakaian dan pembelian bahan baku PT Barata Indonesia (Persero) dapat mendukung penyajian data kuantitas pesanan atau tingkat persediaan rata-rata. Berdasarkan hasil wawancara pada bagian gudang workshop 1 PT Barata Indonesia (Persero) persediaan akhir pada tahun 2016sebesar 350 ton untuk Pasir Silika, 40 ton untuk Fero Silikon, 205 ton untuk Fero Mangan Mc, 60 ton untuk Fero Mangan Hc, dan 1200 ton untuk Scrap. Persediaan akhir tersebut merupakan persediaan awal pada awal periode 2017. Berikut merupakan kuantitas pesanan atau tingkat persediaan rata-rata selama tahun 2017 sebelum menggunakan metode EOQ (Economic Order Quality) adalah sebagai berikut:

Tabel 4.1 Kuantitas Pemesanan atau Tingkat Persediaan Rata-Rata Pasir Silika Tahun 2017.

\begin{tabular}{|l|r|r|r|r|r|r|}
\hline \multicolumn{1}{|c|}{ Bulan } & $\begin{array}{r}\text { Persediaan } \\
\text { Awal (Ton) }\end{array}$ & $\begin{array}{r}\text { Pembelian } \\
\text { (Ton) }\end{array}$ & $\begin{array}{r}\text { Total } \\
\text { Persediaan } \\
\text { Awal (Ton) }\end{array}$ & $\begin{array}{r}\text { Penggunaan } \\
\text { (Ton) }\end{array}$ & $\begin{array}{r}\text { Total } \\
\text { Persediaan } \\
\text { Akhir (Ton) }\end{array}$ & $\begin{array}{r}\text { Persediaan } \\
\text { Rata-Rata } \\
\text { (Ton) }\end{array}$ \\
\hline Januari & 350 & & 350 & 300 & 50 & 200 \\
\hline Februari & 50 & 650 & 700 & 300 & 400 & 550 \\
\hline Maret & 400 & 700 & 1100 & 340 & 760 & 930 \\
\hline April & 760 & 750 & 1510 & 500 & 1010 & 1260 \\
\hline Mei & 1010 & 800 & 1810 & 550 & 1260 & 1535 \\
\hline Juni & 1260 & 800 & 2060 & 560 & 1500 & 1780 \\
\hline Juli & 1500 & 1200 & 2700 & 1000 & 1700 & 2200 \\
\hline Agustus & 1700 & 1140 & 2840 & 1200 & 1640 & 2240 \\
\hline September & 1640 & 1140 & 2780 & 1220 & 1560 & 2170 \\
\hline Oktober & 1560 & 1420 & 2980 & 1500 & 1480 & 2230 \\
\hline November & 1480 & 1140 & 2620 & 1550 & 1070 & 1845 \\
\hline Desember & 1070 & 2000 & 3070 & 2000 & 1070 & 2070 \\
\hline Total & 12780 & 11740 & 24520 & 11020 & 13500 & 19010 \\
\hline Rata-Rata & 1065 & 978.3 & 2043.3 & 918.3 & 1125 & 1584.1 \\
\hline Sur & & & & & \\
\hline
\end{tabular}

Sumber: Data Primer diolah, 2018. 
Tabel 4.2 Kuantitas Pemesanan atau Tingkat Persediaan Rata-Rata Fero Silikon Tahun 2017.

\begin{tabular}{|l|r|r|r|r|r|r|}
\hline Bulan & $\begin{array}{r}\text { Persediaan } \\
\text { Awal (Ton) }\end{array}$ & $\begin{array}{r}\text { Pembelian } \\
\text { (Ton) }\end{array}$ & $\begin{array}{r}\text { Total } \\
\text { Persediaan } \\
\text { Awal (Ton) }\end{array}$ & $\begin{array}{r}\text { Penggunaan } \\
\text { (Ton) }\end{array}$ & $\begin{array}{r}\text { Total } \\
\text { Persediaan } \\
\text { Akhir (Ton) }\end{array}$ & $\begin{array}{r}\text { Persediaan } \\
\text { Rata-Rata } \\
\text { (Ton) }\end{array}$ \\
\hline Januari & 40 & & 40 & 20 & 20 & 30 \\
\hline Februari & 40 & 76 & 116 & 68 & 48 & 82 \\
\hline Maret & 48 & 86 & 134 & 76 & 58 & 96 \\
\hline April & 58 & 80 & 138 & 80 & 58 & 98 \\
\hline Mei & 58 & 100 & 158 & 100 & 58 & 108 \\
\hline Juni & 58 & 120 & 178 & 150 & 28 & 103 \\
\hline Juli & 28 & 170 & 198 & 160 & 38 & 118 \\
\hline Agustus & 38 & 1100 & 1138 & 300 & 838 & 988 \\
\hline September & 838 & 1000 & 1838 & 350 & 1488 & 1663 \\
\hline Oktober & 1488 & 250 & 1738 & 400 & 1338 & 1538 \\
\hline November & 1338 & 250 & 1588 & 420 & 1168 & 1378 \\
\hline Desember & 1168 & 260 & 1428 & 450 & 978 & 1203 \\
\hline Total & 5200 & 3492 & 8692 & 2574 & 6118 & 7405 \\
\hline Rata-Rata & 433.3 & 291 & 724.3 & 214.5 & 509.8 & 617.0 \\
\hline
\end{tabular}

Sumber: Data Primer diolah, 2018.

Tabel 4.4. Kuantitas Pemesanan atau Tingkat Persediaan Rata-Rata Fero Mangan Mc.

\begin{tabular}{|l|r|r|r|r|r|r|}
\hline \multicolumn{1}{|c|}{ Bulan } & $\begin{array}{r}\text { Persediaan } \\
\text { Awal (Ton) }\end{array}$ & $\begin{array}{r}\text { Pembelian } \\
\text { (Ton) }\end{array}$ & $\begin{array}{r}\text { Total } \\
\text { Persediaan } \\
\text { Awal (Ton) }\end{array}$ & $\begin{array}{r}\text { Penggunaan } \\
\text { (Ton) }\end{array}$ & $\begin{array}{r}\text { Total } \\
\text { Persediaan } \\
\text { Akhir(Ton) }\end{array}$ & $\begin{array}{r}\text { Persediaan } \\
\text { Rata-Rata } \\
\text { (Ton) }\end{array}$ \\
\hline Januari & 205 & 205 & 2 & 203 & 204 \\
\hline Februari & 203 & 3 & 206 & 3 & 203 & 204.5 \\
\hline Maret & 203 & 4 & 207 & 4 & 203 & 205 \\
\hline April & 203 & 5 & 208 & 4 & 204 & 206 \\
\hline Mei & 204 & 8 & 212 & 6 & 206 & 209 \\
\hline Juni & 206 & 10 & 216 & 12 & 204 & 210 \\
\hline Juli & 204 & 20 & 224 & 30 & 194 & 209 \\
\hline Agustus & 194 & & 194 & 70 & 124 & 159 \\
\hline September & 124 & & 124 & 120 & 4 & 64 \\
\hline Oktober & 4 & 100 & 104 & & 104 & 104 \\
\hline November & 104 & 100 & 204 & 200 & 4 & 104 \\
\hline Desember & 4 & 500 & 504 & 350 & 154 & 329 \\
\hline Jumlah & 1858 & 750 & 2608 & 801 & 1807 & 2207.5 \\
\hline
\end{tabular}




\begin{tabular}{|c|c|c|c|c|c|c|}
\hline Rata-rata & 154.8 & 62.5 & 217.3 & 66.7 & 150.5 & 183.9 \\
\hline
\end{tabular}

Sumber: Data Primer diolah, 2018.

Tabel 4.5 Kuantitas Pemesanan atauTingkat Persediaan Rata-Rata Fero Mangan Hc.

\begin{tabular}{|l|r|r|r|r|r|r|}
\hline \multicolumn{1}{|c|}{ Bulan } & $\begin{array}{r}\text { Persediaan } \\
\text { Awal (Ton) }\end{array}$ & $\begin{array}{c}\text { Pembelian } \\
\text { (Ton) }\end{array}$ & $\begin{array}{c}\text { Total } \\
\text { Persediaan } \\
\text { Awal (Ton) }\end{array}$ & $\begin{array}{r}\text { Penggunaan } \\
\text { (Ton) }\end{array}$ & $\begin{array}{r}\text { Total } \\
\text { Persediaan } \\
\text { Akhir (Ton) }\end{array}$ & $\begin{array}{c}\text { Persediaan } \\
\text { Rata-Rata } \\
\text { (Ton) }\end{array}$ \\
\hline Januari & 60 & & 60 & 40 & 20 & 40 \\
\hline Februari & 20 & 52 & 72 & 50 & 22 & 47 \\
\hline Maret & 22 & 55 & 77 & 65 & 12 & 44.5 \\
\hline April & 12 & 68 & 80 & 65 & 15 & 47.5 \\
\hline Mei & 15 & 75 & 90 & 80 & 10 & 50 \\
\hline Juni & 10 & 80 & 90 & 80 & 10 & 50 \\
\hline Juli & 10 & 100 & 110 & 88 & 22 & 66 \\
\hline Agustus & 22 & 200 & 222 & 120 & 102 & 162 \\
\hline September & 102 & 200 & 302 & 140 & 162 & 232 \\
\hline Oktober & 162 & 210 & 372 & 190 & 182 & 277 \\
\hline November & 182 & 210 & 392 & 200 & 192 & 292 \\
\hline Desember & 192 & 220 & 412 & 230 & 182 & 297 \\
\hline Jumlah & 809 & 1470 & 2279 & 1348 & 931 & 1605 \\
\hline Rata-rata & 67.4 & 122.5 & 189.9 & 112.3 & 77.5 & 133.7 \\
\hline
\end{tabular}

Sumber: Data Primer diolah, 2018.

Tabel 4.6 Kuantitas Pemesanan atau Tingkat Persediaan Rata-Rata Scrap.

\begin{tabular}{|l|r|r|r|r|r|r|}
\hline Bulan & $\begin{array}{r}\text { Persediaan } \\
\text { Awal (Ton) }\end{array}$ & $\begin{array}{r}\text { Pembelian } \\
\text { (Ton) }\end{array}$ & $\begin{array}{r}\text { Total } \\
\text { Persediaan } \\
\text { Awal (Ton) }\end{array}$ & $\begin{array}{r}\text { Penggunaan } \\
\text { (Ton) }\end{array}$ & $\begin{array}{r}\text { Total } \\
\text { Persediaan } \\
\text { Akhir (Ton) }\end{array}$ & $\begin{array}{r}\text { Persediaan } \\
\text { Rata-Rata } \\
\text { (Ton) }\end{array}$ \\
\hline Januari & 1200 & & 1200 & 1000 & 200 & 700 \\
\hline Februari & 200 & 3600 & 3800 & 1200 & 2600 & 3200 \\
\hline Maret & 2600 & 4000 & 6600 & 1400 & 5200 & 5900 \\
\hline April & 5200 & 4400 & 9600 & 1800 & 7800 & 8700 \\
\hline Mei & 7800 & 4800 & 12600 & 1750 & 10850 & 11725 \\
\hline Juni & 10850 & 5000 & 15850 & 1780 & 14070 & 14960 \\
\hline Juli & 14070 & 9,000 & 23070 & 2600 & 20470 & 21770 \\
\hline Agustus & 20470 & 10,000 & 30470 & 3800 & 26670 & 28570 \\
\hline September & 26670 & 10,000 & 36670 & 5800 & 30870 & 33770 \\
\hline Oktober & 30870 & 15,000 & 45870 & 6500 & 39370 & 42620 \\
\hline
\end{tabular}




\begin{tabular}{|l|r|r|r|r|r|r|} 
November & 39370 & 15,000 & 54370 & 8000 & 46370 & 50370 \\
\hline Desember & 46370 & 20,000 & 66370 & 10000 & 56370 & 61370 \\
\hline Jumlah & 205670 & 100800 & 306470 & 45630 & 260840 & 283655 \\
\hline Rata-Rata & 17139.1 & 8400 & 25539.1 & 3802.5 & 21736.6 & 23637.9 \\
\hline
\end{tabular}

Sumber: Data Primer diolah, 2018.

Tingkat persediaan rata-rata tersebut merupakan hasil rata-rata dari penjumlahan total persediaan awal dengan total persediaan akhir dibagi dua.

Dari tabel diatas dapat dilihat bahwa kuantitas pesanan atau persediaan rata-rata produksi Bogie 9-C selama tahun 2017 yaitu: bahan baku Pasir Silika sebesar 1584,1 ton atau 1584 ton, bahan baku Fero Silikon sebesar 617,0ton atau 671 ton, bahan baku Fero Mangan Mc sebesar 183,9 ton atau 184 ton, bahan baku Fero Mangan Hc sebesar 133,7 ton atau 134 ton, dan bahan baku Scrap sebesar 23637,9 ton atau 23638 ton.

Tabel 4.14 Komponen Total Biaya Persediaan.

\begin{tabular}{|c|c|c|c|c|}
\hline Bahan Baku & $\begin{array}{l}\text { Biaya Pemesanan } \\
\text { (Rp) }\end{array}$ & $\begin{array}{l}\text { Frekuensi } \\
\text { Pemesanan } \\
\text { Aktual (kali) }\end{array}$ & $\begin{array}{l}\text { Biaya Penyimpanan } \\
(\mathrm{Rp})\end{array}$ & $\begin{array}{l}\text { Persediaan } \\
\text { Rata-Rata } \\
\text { (Ton) }\end{array}$ \\
\hline Pasir Silika & $\operatorname{Rp} 826,500,000$ & 11 & Rp 15,000,000 & 1584 \\
\hline Fero Silikon & $\operatorname{Rp} 193,050,000$ & 11 & $\operatorname{Rp} 15,000,000$ & 617 \\
\hline Fero Mangan Mc & $\operatorname{Rp} 166,875,000$ & 9 & $\operatorname{Rp} 15,000,000$ & 184 \\
\hline Fero Mangan Hc & $\operatorname{Rp} 101,100,000$ & 11 & $\operatorname{Rp} 15,000,000$ & 134 \\
\hline Scrap & $\operatorname{Rp} 4,225,000,000$ & 11 & $\operatorname{Rp} 15,000,000$ & 23638 \\
\hline
\end{tabular}

Sumber: Data Primer diolah, 2018.

Tabel 4.15 Total Biaya Persediaan Bahan Baku Aktual Tahun 2017.

\begin{tabular}{|l|l|l|l|}
\hline Bahan Baku & Biaya Pemesanan & Biaya Penyimpanan & Total Biaya Persediaan \\
\hline Pasir Silika & Rp 9,091,500,000 & Rp 23,760,000,000 & Rp 32,851,500,000 \\
\hline Fero Silikon & Rp 2,123,550,000 & Rp 9,255,000,000 & Rp 11,378,550,000 \\
\hline Fero Mangan Mc & Rp 1,501,875,000 & Rp 2,760,000,000 & Rp 4,261,875,000 \\
\hline Fero Mangan Hc & Rp 1,112,100,000 & Rp 2,010,000,000 & Rp 3,122,100,000 \\
\hline Scrap & Rp46,475,000,000 & Rp354,570,000,000 & Rp401,045,000,000 \\
\hline
\end{tabular}

Sumber: Data Primer diolah, 2018.

Data tabel diatas dapat diketahui bahwa komponen biaya persediaan bahan baku yang menimbulkan biaya yang paling besar adalah biaya pemesanan, yaitu: Pasir Silika sebesar Rp 826,500,000, Fero Silikon sebesar Rp 193,050,000, Fero Mangan Mc sebesar Rp 166,875,000, Fero Mangan Hc sebesar Rp 101,100,000 dan Scrap sebesar Rp 4,225,000,000. Adapun untuk total 
persediaan bahan baku aktual perusahaan yaitu: untuk Pasir Silika sebesar Rp 32,851,500,000, Fero Silikon sebesar Rp 11,378,550,000, Fero Mangan Mc Rp 4,261,875,000, Fero Mangan Hc Rp 3,122,100,000 dan Scrap sebesar Rp 401,045,000,000.

\subsubsection{Analisis Pengendalian Persediaan Bahan Baku Dengan Menggunakan Metode EOQ (Economic Order Quality).}

\subsubsection{Perhitungan Metode EOQ (Economic Order Quality).}

Perhitungan analisis pengendalian persediaan bahan baku dapat digunakan dengan metode EOQ (Economic Order Quality). Hal ini dapat dilakukan karena terpenuhinya semua asumsi kondisi, karakteristik, serta kebutuhan perusahaan. Perusahaan memiliki data permintaan yang diketahui tetap dan bebas. Selain itu, lead time konstan, penerimaan persediaan bersifat seketika dan lengkap, biaya variabel yang ada hanyalah biaya pesanan dan biaya penyimpanan, serta kosongnya persediaan dapat dihindari sepenuhnya jika pesanan dilakukan pada waktu yang tepat.

Tabel 4.16 Perhitungan Metode EOQ (Economic Order Quality) Bahan Baku Bogie C-9 Tahun 2017.

\begin{tabular}{|l|r|r|l|l|}
\hline Bahan Baku & Permintaan & Biaya Pemesanan & $\begin{array}{l}\text { Piaya } \\
\text { Penyimpanan }\end{array}$ & EOQ \\
\hline Pasir Silika & 11020 ton & $\mathrm{Rp} 826,500,000$ & $\mathrm{Rp} \mathrm{15,000,000}$ & 1102 ton \\
\hline Fero Silikon & 2574 ton & $\mathrm{Rp} 193,050,000$ & $\mathrm{Rp} \mathrm{15,000,000}$ & 257.4 ton \\
\hline $\begin{array}{l}\text { Fero Mangan } \\
\text { Mc }\end{array}$ & 801 ton & $\mathrm{Rp} 166,875,000$ & $\mathrm{Rp} \mathrm{15,000,000}$ & 133.5 ton \\
\hline $\begin{array}{l}\text { Fero Mangan } \\
\text { Hc }\end{array}$ & 1348 ton & $\mathrm{Rp} 101,100,000$ & $\mathrm{Rp} 15,000,000$ & 134.8 ton \\
\hline Scrap & 45630 ton & $\mathrm{Rp} \mathrm{4,225,000,000}$ & $\mathrm{Rp} \mathrm{15,000,000}$ & 5070 ton \\
\hline
\end{tabular}

Sumber: Data Primer diolah, 2018.

Berdasarkan perhitungan metode EOQ (Economic Order Quality) produksi Bogie 9-C pada tabel diatas dapat diketahui bahwa kuantitas pesanan optimal (EOQ) selama tahun 2017 yaitu: bahan baku pasir silikon sebesar 1102 ton setiap kali pemesanan, Fero Silikon sebesar 257,4 ton atau 257 ton setiap kali pemesanan, Fero Mangan Mc sebesar 133,5 ton atau 134 tonsetiap kali pemesanan, Fero Mangan Hc sebesar 134,8 atau 135 ton setiap kali pemesanan, Scrap sebesar 5070 ton setiap kali pemesanan.

Setelah mengetahui kuantitas pesanan optimal (EOQ) setiap kali pesanan pada tahun 2017, maka frekuensi pemesanan bahan baku produksi Bogie 9-C dapat dihitung. Berikut merupakan tabel perhitungan untuk frekuensi pemesanan optimal produksi Bogie 9-C tahun 2017: 
Tabel 4.17 Frekuensi Pemesanan Optimal Bahan Baku Produksi Bogie 9-C tahun 2017.

\begin{tabular}{|c|c|c|c|}
\hline Bahan Baku & $\begin{array}{l}\text { Penggunaan } \\
\text { (Ton) }\end{array}$ & $\begin{array}{l}\text { EOQ } \\
\text { (Ton) }\end{array}$ & $\begin{array}{l}\text { Frekuensi } \\
\text { Pesanan (kali) }\end{array}$ \\
\hline Pasir Silika & 11020 & 1102 & 10 \\
\hline Fero Silikon & 2574 & 257.4 & 10 \\
\hline Fero Mangan Mc & 801 & 133.5 & 6 \\
\hline Fero Mangan Hc & 1348 & 134.8 & 10 \\
\hline Scrap & 45630 & 5070 & 9 \\
\hline
\end{tabular}

Sumber: Data Primer diolah, 2018.

Dari tabel diatas Frekuensi Pemesanan Optimal produksi Bogie 9-C tahun 2017 dengan menggunakan metode EOQ (Economic Order Quality) yaitu bahan baku Pasir Silika sebanyak 10 kali pemesanan, Fero Silikon sebanyak 10 kali pemasanan, Fero Mangan Mc sebanyak 6 kali pemesanan, Fero Mangan Hc sebanyak 10 kali pemesanan, dan Scrap sebanyak 9 kali pemesanan.

\subsubsection{Safety Stock (Biaya Pengamanan)}

Persediaan pengamanan merupakan suatu persediaan yang dicadangkan sebagai pengamanan dari kelangsungan proses produksi perusahaan. Persediaan pengamanan diperlukan karena dalam kenyataannya jumlah bahan baku yang diperlukan untuk proses produksi tidak seperti yang direncanakan. Berikut merupakan perhitungan standar devisiasi:

Tabel 4.20 Perhitungan Safety Stock (Persediaan Pengamanan).

\begin{tabular}{|l|r|r|r|}
\hline Bahan Baku & Standar Devisiasi & $\begin{array}{l}\text { Devisiasi } \\
\text { Kepercayaan }\end{array}$ & $\begin{array}{l}\text { Safety } \\
\text { Stock(Ton) }\end{array}$ \\
\hline Pasir Silika & 549 & 1.65 & 907 \\
\hline Fero Silikon & 151 & 1.65 & 249 \\
\hline Fero Mangan Mc & 104 & 1.65 & 171 \\
\hline Fero Mangan Hc & 61 & 1.65 & 4798 \\
\hline Scrap & 2908 & 1.65 & 101 \\
\hline
\end{tabular}

Sumber: Data Primer diolah, 2018.

Dari tabel diatas standar devisiasi yang standar devisiasi yang dihasilkan untuk bahan baku Pasir Silika sebesar 549 ton, untuk Fero Silikon sebesar 151 ton, untuk Fero Mangan Mc sebesar 104 ton, untuk Fero Mangan Hc sebesar 61 ton, untuk Scrap sebesar 2908 ton. Sedangkan tingkat pelayanannya sebesar 95\% menunjukkan bahwa besarnya kemungkinan permintaan tidak akan melebihi persediaan selama waktu tenggang yaitu 95\%. Risiko terjadinya kekurangan persediaan (Stock Out Risk) hanya 5\%. PT Barata Indonesia (Persero) menggunakan standar divisiasi sebesar $5 \%$ dengan nilai 1.65. Sehingga menghasilkan persediaan pengamanan (Safety Stock) untuk bahan 
baku Pasir Silika sebesar 907 ton, untuk Fero Silikon sebesar 249 ton, untuk Fero Mangan Mc sebesar 171 ton, untuk Fero Mangan Hc sebesar 101 ton, untuk Scrap sebesar 4798 ton.

\subsubsection{Reorder Point (Pemesanan Kembali).}

Metode yang telah dilakukan oleh perusahaan secara aktual dapat dibandingkan dengan metode EOQ (Economic Order Quality). Dengan mengetahui hasil perbandingannya, maka perusahaan akan mengetahui metode mana yang akan menghasilkan biaya paling optimal dan lebih efektif bagi perusahaan bila diterapkan dan akan menghasilkan keuntungan.

Pemesanan kembali adalah tingkat persediaan dimana untuk mengisis ulang persediaan barang. Hal ini bertujuan agar perusahaan dapat mengetahui kapan waktu yang tepat untuk melakukan pesanan. Pemesanan kembali(Reorder Point)dapat dihitung dengan menjumlahkan kebutuhan bahan baku selama waktu tunggu (Lead Time)ditambah dengan jumlah persediaan pengamanan (Safety Stock). Waktu tunggu yang muncul akibat menunggu tibanya bahan baku. Berikut merupakan pemesanan kembali produksi Bogie 9-C tahun 2017.

Tabel 4.21 Perhitungan Pemesanan Kembali (Reorder Point).

\begin{tabular}{|l|l|l|r|r|r|}
\hline Bahan Baku & $\begin{array}{l}\text { Waktu } \\
\text { Tunggu } \\
\text { (lead time })\end{array}$ & $\begin{array}{l}\text { Permintaan } \\
\text { Perhari }\end{array}$ & $\mathrm{dL}$ & SS (ton) & $\begin{array}{l}\text { ROP } \\
(\mathrm{dL}+\mathrm{SS})\end{array}$ \\
\hline Pasir Silika & 3 & 31 & 93 & 907 & 1000 \\
\hline Fero Silikon & 3 & 7 & 21 & 249 & 270 \\
\hline Fero Mangan Mc & 3 & 2 & 6 & 171 & 177 \\
\hline Fero Mangan Hc & 3 & 4 & 12 & 101 & 113 \\
\hline Scrap & 3 & 127 & 381 & 4798 & 5178 \\
\hline
\end{tabular}

Sumber: Data Primer diolah, 2018.

\subsubsection{Perbandingan Pengendalian Persediaan Bahan Baku berdasarkan perusahaan Dan Metode EOQ (Economic Order Quality).}

Metode yang telah dilakukan oleh perusahaan dibandingkan dengan metode EOQ (Economic Order Quality). Dengan mengetahui hasil perbandingannya, maka perusahaan akan mengetahui metode mana yang akan menghasilkan biaya paling optimal dan lebih efektif bagi perusahaan bila diterapkan dan akan menghasilkan keuntungan. 
Tabel 4.8 Perbandingan Biaya Bahan Baku Fero Mangan Mc Tahun 2017.

\begin{tabular}{|c|c|c|c|}
\hline Uraian & Perusahaan & Metode EOQ & Penghematan \\
\hline $\begin{array}{l}\text { Kuantitas } \\
\text { Pemesanan }\end{array}$ & 184 ton & 134 ton & 50 ton \\
\hline $\begin{array}{l}\text { Biaya } \\
\text { Pemesanan }\end{array}$ & $\operatorname{Rp} 1,501,875,000$ & $\operatorname{Rp} 1,001,250,000$ & $\mathrm{Rp} \quad 500,625,000$ \\
\hline $\begin{array}{l}\text { Biaya } \\
\text { Penyimpanan }\end{array}$ & $\operatorname{Rp} 2,760,000,000$ & $\operatorname{Rp} 1,005,000,000$ & Rp1,755,000,000 \\
\hline $\begin{array}{l}\text { Total Biaya } \\
\text { Persediaan }\end{array}$ & $\operatorname{Rp} 4,261,875,000$ & $\operatorname{Rp} \quad 2,006,250,000$ & $\mathrm{Rp} 2,255,625,000$ \\
\hline
\end{tabular}

Sumber: Data Primer diolah, 2018.

Tabel 4.9 Perbandingan Biaya Bahan Baku Fero Mangan Hc Tahun 2017.

\begin{tabular}{|c|c|c|c|}
\hline Uraian & Perusahaan & Metode EOQ & Penghematan \\
\hline $\begin{array}{l}\text { Kuantitas } \\
\text { Pemesanan }\end{array}$ & 134 ton & 135 ton & \\
\hline $\begin{array}{l}\text { Biaya } \\
\text { Pemesanan }\end{array}$ & Rp $1,112,100$ & $\mathrm{Rp} \quad 1,011,000$ & Rp 101,100 \\
\hline $\begin{array}{l}\text { Biaya } \\
\text { Penyimpanan }\end{array}$ & $\operatorname{Rp} \quad 2,010,000$ & $\mathrm{Rp} \quad 1,012,500$ & Rp 997,500 \\
\hline $\begin{array}{l}\text { Total Biaya } \\
\text { Persediaan }\end{array}$ & $\operatorname{Rp} 3,122,100$ & $\mathrm{Rp} \quad 2,023,500$ & Rp1,098,600 \\
\hline
\end{tabular}

Sumber: Data Primer diolah, 2018.

Tabel 4.10 Perbandingan Biaya Bahan Baku Scrap Tahun 2017.

\begin{tabular}{|l|l|l|l|}
\hline Uraian & Perusahaan & Metode EOQ & Penghematan \\
\hline $\begin{array}{l}\text { Kuantitas } \\
\text { Pemesanan }\end{array}$ & 23638 ton & 5070 ton & 15868 ton \\
\hline $\begin{array}{l}\text { Biaya } \\
\text { Pemesanan }\end{array}$ & Rp 46,475,000 & Rp 38,025,000 & Rp 8,450,000 \\
\hline $\begin{array}{l}\text { Biaya } \\
\text { Penyimpanan }\end{array}$ & Rp354,570,000 & Rp 38,025,000 & Rp316,545,000 \\
\hline $\begin{array}{l}\text { Total Biaya } \\
\text { Persediaan }\end{array}$ & Rp401,045,000 & Rp 76,050,000 & Rp324,995,000 \\
\hline
\end{tabular}

Sumber: Data Primer diolah, 2018.

Dari tabel diatas dapat diketahui bahwa terjadi penghematan pada kuantitas pemesanan yaitu pada bahan baku pasir Silika sebanyak 482 ton setiap kali pemesanan, Fero Silikon 
sebanyak 360 ton setiap kali pemesanan, Fero Mangan Mc sebanyak 50 setiap kali pemesanan, Scrap sebanyak 18568 ton setiap kali pemesanan. Dan untuk biaya dengan menggunakan metode EOQ (Economic Order Quality) perusahaan dapat meminimalkan biaya yaitu biaya pemesanan dan biaya penyimpanan. Untuk biaya pemesanan pada bahan baku Pasir Silika sebesar Rp 826,500, Fero Silikon sebesar Rp 193,050,000, Fero Mangan Mc sebesar Rp 500,625,000, Fero Mangan Hc sebesar Rp 101,100, Scrap sebesar Rp 8,450,000, dan biaya penyimpanan untuk bahan baku Pasir Silika sebesar Rp 15,495,000 Fero Silikon sebesar Rp 7,327,500,000, Fero Mangan Mc sebesar Rp 1,755,000,000, Fero Mangan Hc sebesar Rp 997,500, Scrap sebesar Rp 316,545,000 Sehingga total biaya persediaan juga mengalami penghemtan yaitu untuk bahan baku Pasir Silika sebesar Rp 16,321,500, Fero Silikon sebesar Rp 7,520,550,000, Fero Mangan Mc sebesar Rp 2,255,625,000, Fero Mangan Hc sebesar Rp 1,098,600, Scrap sebesar Rp $324,995,000$,

\section{KESIMPULAN, IMPLIKASI DAN KETERBATASAN}

Pengendalian bahan baku dengan menggunakan metode EOQ (Economic Order Quallity) dapat meminimalisir biaya produksi pada PT Barata Indonesia (Persero) yaitu sebagai berikut:

a. Bahan baku Pasir Silika dapat meminimalisir biaya produksi sebesar Rp 16,321,500.

b. Bahan baku Fero Silikon dapat meminimalisir biaya produksi sebesar Rp 7,520,550,000.

c. Bahan baku Fero Mangan Mc dapat meminimalisir biaya sebesar Rp 2,255,625,000.

d. Bahan baku Fero Mangan Hc dapat meminimalisir biaya sebesar Rp 1,098,600.

e. Bahan baku Scrap dapat meminimalisir biaya sebesar Rp 324,995,000.

Untuk dapat menekan biaya produksi, perusahaan tentunya harus meminimumkan total biaya persediaan. Perusahaan sebaiknya menggunakan metode EOQ (Economic Order Quantity) karena dengan metode EOQ (Economic Order Quality) perusahaan dapat mengoptimalkan persediaan dan meminimalkan biaya.

\section{URGENSI (KEUTAMAAN) PENELITIAN}

Hasil penelitian memberikan masukan agar dapat mengambil langkah dan keputusan guna melakukan persiapan dan perbaikan demi kemajuan perusahaan tersebut serta memberikan gambaran dan harapan yang baik terhadap perusahaan tersebut. Melalui penelitian ini diharapkan penulis akan memperdalam pengetahuan dalam bidang manajemen operasional khususnya masalah pengendalian persediaan bahan baku dari big data. Dari penulisan penelitian ini diharapkan dapat dijadikan sumber informasi dan referensi bagi penulis lainnya khususnya dalam bidang manajemen operasional mengenai pengendalian bahan baku. Dengan data yang tersimpan harus akurat sesuaidengandata yang ada dilapangan. 


\section{DAFTAR PUSTAKA}

Arikunto, S. (2005). Manajemen Penelitian . Jakarta: Rineka Cipta.

Assauri, S. (2004). Manajemen Operasi dan Produksi . Jakarta: PT Jaya Grafindo Persada.

Baroto, T. (2006). Perencanaan Dan Pengendalian Produksi. Jakarta: Ghalia Indonesia.

Daryanto, S. (2007). Analisis Pengendalian Bahan Baku Terhadap Efesiensi Biaya pada PT.Menara Cipta Metalindo. Jurnal Administrasi Kantor Vol 3 No 2 Agustus 2015 , 9.

Daud, M. N. (2017). Analisis Pengendalian Persediaan Bahan Baku Produksi Roti Wilton Kualasimpang. Jurnal Samudra Ekonomi dan Bisnis, Vol.8, No.2 .

Fajrin, E. H. (2016). Analisis Pengendalian Persediaan Bahan Baku Dengan Menggunakan Metode Economic Order Quality (EOQ) pada Perusahaan Roti Bonansa. Managemen Analisi Joural , 1-10.

Handoko, H. T. (2011). Dasar-Dasar Manajemen Produksi Dan Operasi, Edisi 1. Yogyakarta: BPFE Fakultas Ekonomi UGM.

Heizer, J. d. (2015). Manajemen Operasi:Keberlangsungan dan Rantai Pasokan. Edisi 11. Jakarta: Salemba Empat.

Kuncoro, M. (2011). Metode Penelitian . Jakarta : PT.Erlangga.

Manullang, M. (2005). Dasar-Dasar Manajemen . Yogyakarta: Gajah Mada University.

Mulyadi. (2014). Akuntansi Biaya Edisi lima . Yogyakarta: UPP STIM YKPN .

Maizawati (2017). Siab online sebagai solusi internet of things Transportasi Logistic eJurnal Manejemen Indonesia , 39-48.

Natalia, F. (2017). Analisis Pengendalian Persediaan Bahan Baku Dengan Menggunakan Metode EOQ (Economic Order Quality) pada Primed Konvekdi Di Samarinda. eJurnal Administrasi Bisnis , 10651075.

Nurjamuddin. (2012). Analisis Efesiensi Pengendalian Persediaan Bahan Baku Setengah Jadi Dengan Menggunakan Metode EOQ (Economic Order Quantity) pada PT.Utama Harmoni Sejahtera di Samarinda. eJournal Administrasi Bisnis , 5.

Pardede, P. M. (2005). Manajemen Operasi dan Produksi . Jakarta: Andi Offset.

Rahmawan, A. (2016). Analisis Pengendalian Persediaan Bahan Pelumas dan Bahan Kimia Untuk Menunjang Produksi Pada PT.Meratus Jaya Iron dan Steel di Batulicin. Jurnal Ilmiah Ekonomi Bisnis, Vol 2, No 1, 143-150.

Rambung, A. L. (2017). Analisis Efesiensi Pengendalian Persediaan Bahan Setengah Jadi Dengan Metode EOQ (Economic Order Quality) pada PT Utama Harmoni Sejahtera di Samarinda. eJournal Administrasi Bisnis .

Rangkuti, F. (2004). Manajemen Persediaan Aplikasi di Bidang Bisnis . Jakarta: PT Grafindo Persada.

Sugiyono. (2015). Metode Penelitian. Bandung : Alfabeta.

Sugiyono. (2016). Metode Penelitian. Bandung: Alfabeta.

Suryono, D. (2013). Metodelogi Penelitian Kualitatif dan Kuantitatif dallam Bidang Kesehatan . Yogyakarta: Nuha Medika. 
Taroleh, G. d. (2016). Analisis Persediaan Bahan Baku Di Rumah Makan Sabuah Oki-Manado. Jurnal Berkala Ilmiah Efesiensi , 1-10.

Trihudiyatmanto, M. (2017). Analisis Pengendalian Bahan Baku Dengan Menggunakan Metode Economic Order Quality (EOQ) (Studi Empiris pada CV Jaya Gemilang Wonosobo). Jurnal PPKM III (2017) 220 - 234 Program Studi Manajemen Fakultas Ekonomi .

Usry, C. (2006). Akuntansi Biaya . Jakarta: Salemba Empat.

Wijaya, D. d. (2016). Analisis Pebngendalian Bahan Baku Ikan pada PT.Celebes Minapratama Bitung. Jurnal EMBA, 578-591. 